\title{
Line Management's Involvement in People Management: A Comparison between South Africa and Australia
}

\section{Leo Vermeulen}

\section{Human Resources Management, University of Pretoria}

\begin{abstract}
The purpose of this study was to obtain empirical data on expected shifts of people management activities from human resources managers to line managers. The research was done by means of a cross-cultural survey in South Africa $(n=381)$ and Australia $(n=653)$. The research results clearly indicate that there was a perceived shift of traditional people management functions to line management in both countries. This shift was more prominent in South Africa than in Australia. The main shift in South Africa seemed to be that line managers are increasingly involved in training and development. Equal employment opportunity was seen as the second most important area of change, followed by the use of human resources information systems, industrial relations, and occupational health and safety. Recruitment and selection were seen as the least important areas of change.
\end{abstract}

JEL J50, J59

\section{INTRODUCTION}

Organisations in South Africa are subject to major changes in the way that people are managed. This transformation can be ascribed to the introduction of these organisations in global markets, to socio-political changes, to new legal requirements, to new information systems, to the demand for a more skilled work force, to increasing attention to diversity in the work force, as well as to higher customer and shareholder expectations. Successful transformation requires traditional structures and roles to be shed and more flexible practices for managing people in varied and changing conditions to be adopted (Noe, Hollenbeck, Gerhart \& Wright, 2000).

As organisations begin to compete in the challenging business environment of the new millennium, the reason for success increasingly lies in effective human resources management (Byars \& Rue, 2000: 4). Human resources management 
consists of a set of ideas, policies and practices which management adopts in order to achieve a people-management objective (Tyson, 1995: 3). In this article, the concepts "human resources management" and "people management" are used interchangeably.

According to the latest thinking by prominent and respected human resources experts (Gratton, 1997; Hunter, 1997; Kemske, 1998; Laabs, 2000; Ulrich, 1998a, 1998b), the human resources function will have to shed its traditional administrative, compliance and service role, and instead will have to adopt a strategic role in developing the organisation and the capabilities of its managers. Today's human resources professionals are administrative experts who set up an efficient system design, and deliver that system. They champion employees and ensure that people's contributions (their commitment and competence) remain high. They are agents of change who help business through transformation and change (Bernardin, 2003; Ulrich, 1998a). Both within the people management function and in the rest of the organisation, human resources practitioners are seen to fulfil new roles, to take on new responsibilities and to make new contributions to business. The key change for human resources professionals is the requirement that they be facilitators and agents of change, not just practitioners (Hardijzer, 1998). In this regard, as early as 1987, Gordon (1987) stated that human resources professionals in the 1990s would be likely to focus on increasing the effectiveness of their interaction with line managers and the transfer of some direct human resources management responsibilities to these line managers. Subsequently, the human resources manager would act as

- a provider - offering expertise to assist line managers in human resources management;

- a delegator - assigning personnel roles to managers;

- $\quad$ an auditor - evaluating the performance of line managers in implementing personnel policies;

- an innovator - upgrading the technical competence and access of managers to information; and

- a policy formulator - developing consistent, cost-effective human resources policy (Gordon, 1987: 9).

Organisations are managed and staffed by people. Without people, organisations cannot exist. Indeed, Cascio (2003: 55) claims that the "challenge, the opportunity and also the frustration of creating and managing organisations frequently stems from the people-related problems that arise within them". As "people issues" become more central to business success, line managers are also compelled to get involved in people management. The reason is that line managers are ultimately responsible for both the processes and the outcomes of 
the company. They are answerable to shareholders for creating economic value, to customers for creating product or service value and to employees for creating workplace value (Ulrich, 1998a). It is line management's responsibility to define the strategic context, build the organisation, develop staff capabilities and manage performance.

To be successful, line management should become directly involved in all human resources management practices. A framework for understanding line managers' involvement in people management functions is provided by Gordon (1987: 10-11) and Mathis and Jackson (1997: 16-18). They have suggested several ways in which line managers and human resources practitioners can share people-related business activities. However, the nature of the line managers' responsibilities may vary for different human resources functions. In general, they include the following: line managers should have primary responsibility and accountability for the implementation of the human resources policies developed by top management and human resources professionals. They should systematically perform each human resources function, in other words, human resources planning and analysis, staffing, training and development, equal employment opportunity compliance, employee and labour relations management and the management of occupational health and safety issues. According to Gordon (1987), line managers should continually practice quality, state-of-the-art human resources management. They must be able to use computerized human resources information systems (HRIS) to obtain information so they can act as diagnosticians and assess the effectiveness of current human resources practices and to ensure the effective and efficient use of human capital (talent) to accomplish organisational goals.

The challenge to the human resources staff function in the $21^{\text {st }}$ century will be to enable managers to fulfill this responsibility and pursue continuous improvements in each of the people management areas that are critical to competitive success. Managers should integrate people management with business or service priorities and should become human resources champions themselves. Sufficient knowledge of functions such as staffing, training and development, equal employment opportunities, occupational health and safety, industrial relations, personnel information systems and compensating employees should strengthen line managers and give them a competitive edge (Byars \& Rue, 2000; Lee, 1998).

So far only one overseas study has examined whether the expected shifts of people management activities to line managers has indeed occurred. In 1994/95, Littler, Bramble and Dunford (1995) launched a comprehensive research programme on organisational change in Australia. Their survey of 653 Australian organisations provided a comprehensive picture of organisational 
restructuring and downsizing. These three researchers also gathered data on the involvement of line managers in critical people management activities in the future.

This study was duplicated in South Africa to provide a comparable data base (Vermeulen, Littler \& Wiesner, 1997). South Africa was selected for such a study because its industrial mix and history are comparable to those of Australia. One major difference is that South Africa, after the 1994 elections, has become one of the youngest democratic countries in the world and has embarked on extensive labour reforms and development of its human capital.

The purpose of this article is to report on the findings of the cross-cultural research on the expected shifts of people management activities from human resources managers to line managers.

The research questions addressed in this study are the following:

- To what extent do human resources managers and chief executive officers in South Africa and Australia perceive that line managers will be involved with people management functions in the future?

- Is there a statistical difference between the perceived involvement of line managers in people management functions in South Africa and Australia?

\section{METHOD}

\section{Sampling procedure}

The rationale for the sampling in this study was to obtain a broad cross-section of larger organisations throughout South Africa and Australia. In defining the sample, it should be noted that the unit of analysis was organisations, not individual employees. In both South Africa and Australia, the focus was on larger organisations (employing 100 or more people) and the sample is skewed towards those organisations.

The sampling frame for the South African survey was derived from the professional register of organisations obtained from the South African Board for Personnel Practice. A sample of 1200 names was randomly picked from the register. This sample represents more organisations than only those noted on the Stock Exchange. A questionnaire accompanied by a covering letter was mailed to each respondent chosen for the sample. Of the 1200, 421 questionnaires were returned, of which 381 were usable. This represented a response rate of 31.08 per cent. 
The sample for the Australian survey was derived from the membership of the Australian Human Resources Institute. Of the initial 1722 organisations to which the Australian questionnaire was sent, there was a sample loss of 30 who indicated that their organisations were too small for the questions to make sense. Of the possible 1692 sets of responses, 653 useable questionnaires were returned, a response rate of 38,6 per cent.

The response patterns and the characteristics of the respondents of each country are summarised in Table 1.

Table 1 Characteristics of participating organisations and respondents

\begin{tabular}{|l|c|c|c|c|}
\hline \multicolumn{1}{|c|}{ Variable } & \multicolumn{2}{c|}{ South Africa } & \multicolumn{2}{c|}{ Australia } \\
\hline Sector & N & \% & N & \% \\
\hline Private sector & & & & \\
\hline Public sector & 265 & 69,7 & 447 & 69,8 \\
\hline Number of employees & 115 & 30,3 & 193 & 30,2 \\
\hline$<100$ & & & & \\
\hline $101-1000$ & 36 & 9,4 & 147 & 22,5 \\
\hline$>1000$ & 102 & 26,8 & 275 & 42,2 \\
\hline Industrial profile & 243 & 63,8 & 230 & 35,3 \\
\hline Agriculture & & & & \\
\hline Mining & 16 & 4,2 & 8 & 1,2 \\
\hline Manufacturing & 45 & 11,8 & 25 & 3,8 \\
\hline Electricity and gas & 87 & 22,8 & 129 & 19,8 \\
\hline Construction & 27 & 7,1 & 9 & 1,4 \\
\hline Trade and catering & 8 & 2,1 & 11 & 1,7 \\
\hline Transport, Storage & 31 & 8,1 & 41 & 6,3 \\
\hline Communication & 20 & 5,2 & 18 & 2,8 \\
\hline Financial services & 13 & 3,4 & 28 & 4,3 \\
\hline Public and Community services & 50 & 13,2 & 60 & 9,1 \\
\hline Other & 73 & 19,2 & 82 & 12,5 \\
\hline Current work position & & 2,9 & 242 & 37,1 \\
\hline Executive & 24 & 6,3 & 114 & 17,5 \\
\hline Senior manager & 242 & 63,6 & 362 & 56,5 \\
\hline Middle manager & 115 & 30,1 & 164 & 26,0 \\
\hline Functional level & & & & \\
\hline Human resources management & 329 & 86,4 & 461 & 71,6 \\
\hline General management & 52 & 13,6 & 185 & 28,4 \\
\hline
\end{tabular}


Table 1 continued

\begin{tabular}{|l|c|c|c|c|}
\hline \multicolumn{1}{|c|}{ Variable } & \multicolumn{2}{c|}{ South Africa } & \multicolumn{2}{c|}{ Australia } \\
\hline & N & \% & N & \% \\
\hline Employment period & & & & \\
\hline 1-2 years & 32 & 8,4 & 101 & 15,4 \\
\hline 3-4 years & 50 & 13,1 & 133 & 20,4 \\
\hline 5-6 years & 50 & 13,1 & 113 & 17,3 \\
\hline 7 years+ & 248 & 64,9 & 301 & 46,1 \\
\hline Gender & & & & \\
\hline Female & 58 & 15,2 & 153 & 23,4 \\
\hline Male & 324 & 84,8 & 496 & 76,0 \\
\hline
\end{tabular}

\section{Measuring instrument}

Littler's Organisational Change Survey Questionnaire was used to collect the data. The questionnaire was developed and standardised by Littler, Bramble and Dunford (1995) to measure organisational change in Australia. The questionnaire consists of six sections, namely the organisation, staff numbers, structure and the responsibilities of line managers, workforce reduction, delayering, and demographics. For the purposes of this study, only the section of the questionnaire related to the people management responsibilities of line managers is examined in this article. This section assesses whether line managers' responsibilities with regard to people management functions will increase in future, will remain unchanged or will decrease. The respondents made predictions in 1996 for the next two years (1997 and 1998).

\section{Data analysis}

A descriptive and comparative research design was followed. Descriptive statistics were used to summarise the data (for example, frequencies, percentages and ranking) and inferential statistics were employed to investigate possible differences between groups (Morgan \& Griego, 1998). The choice of the statistical tests was based on the level of measurement achieved in the research (Runyon, 1977). In this study an ordinal scale was used as a level of measurement. Data measured by either nominal or ordinal scales should be analysed by non-parametric methods (Morgan \& Griego, 1998; Runyon, 1977).

The Mann-Whitney U-test was used to determine differences between the two countries (independent variable) regarding line managers' responsibility for people management and human resources functions (dependent variables). This is one of the most powerful of the non-parametric tests and it is a most useful alternative to the parametric $t$-test when the measurement in the research is 
weaker than interval scaling. The SPSS for Windows Statistical Package, Release 9, was applied for all statistical procedures (Morgan \& Griego, 1998).

\section{RESULTS}

Frequencies were calculated for each of the dependent variables (recruitment and selection, training and development, equal employment opportunity, occupational health and safety, industrial relations and human resources information systems) to ascertain whether people management functions have shifted to line management over a two year period.

The frequency analysis indicated that the majority of respondents in South Africa ( $\bar{X}=76,68$ per cent) and Australia ( $\bar{X}=58,12$ per cent $)$ expected that major shifts in people management functions would take place. According to the results, line managers in both countries would become significantly involved with human resources functions in future. The results are set out in Figure 1 and summarised in Table 2.

Table 2 An analysis of the shift of people management activities to line management in South Africa and Australia: percentage and ranking per country

\begin{tabular}{|c|c|c|c|c|c|c|}
\hline \multirow[b]{2}{*}{$\begin{array}{l}\text { Human } \\
\text { resources } \\
\text { functions }\end{array}$} & \multirow[b]{2}{*}{ Country } & \multirow[b]{2}{*}{$\mathbf{N}$} & \multicolumn{3}{|c|}{ Extent } & \multirow[b]{2}{*}{ Rank } \\
\hline & & & $\begin{array}{c}\text { Decreased } \\
\%\end{array}$ & $\begin{array}{c}\text { Un- } \\
\text { changed } \\
\%\end{array}$ & $\begin{array}{c}\text { Increased } \\
\%\end{array}$ & \\
\hline \multirow{2}{*}{$\begin{array}{l}\text { Recruitment } \\
\text { and selection }\end{array}$} & South Africa & 371 & 13,7 & 30,2 & 56,1 & 6 \\
\hline & Australia & 632 & 8,2 & 43,2 & 48,6 & 6 \\
\hline \multirow{2}{*}{$\begin{array}{l}\text { Training and } \\
\text { development }\end{array}$} & South Africa & 375 & 3,5 & 7,2 & 89,3 & 1 \\
\hline & Australia & 627 & 2,7 & 24,7 & 72,6 & 1 \\
\hline \multirow{2}{*}{$\begin{array}{l}\text { Equal } \\
\text { employment } \\
\text { opportunity }\end{array}$} & South Africa & 374 & 2,4 & 12,3 & 85,3 & 2 \\
\hline & Australia & 625 & 1,6 & 45,8 & 52,6 & 4 \\
\hline \multirow{2}{*}{$\begin{array}{l}\text { Occupational } \\
\text { health and } \\
\text { safety }\end{array}$} & South Africa & 371 & 2,2 & 2,8 & 69,8 & 5 \\
\hline & Australia & 627 & 1,3 & 38,3 & 60,4 & 3 \\
\hline \multirow{2}{*}{$\begin{array}{l}\text { Industrial } \\
\text { relations }\end{array}$} & South Africa & 371 & 5,1 & 17,8 & 77,1 & 4 \\
\hline & Australia & 622 & 5,6 & 44,7 & 49,7 & 5 \\
\hline \multirow{2}{*}{$\begin{array}{l}\text { HR } \\
\text { information } \\
\text { systems }\end{array}$} & South Africa & 371 & 2,2 & 14,6 & 83,3 & 3 \\
\hline & Australia & 616 & 1,3 & 33,9 & 64,8 & 2 \\
\hline
\end{tabular}


As is shown in Figure 1 and in Table 2, the main shifts in South Africa seem to be that line managers are increasingly involved in training and development (89,3 per cent), as the most important area of change, followed by equal employment opportunity (85,3 per cent), the use of human resources information systems ( 83,3 per cent), industrial relations ( 77,1 per cent), occupational health and safety $(69,8$ per cent) and recruitment and selection ( 56,1 per cent).

Figure 1 Line managers involvement with people management functions: a comparison between South Africa and Australia

Recruitment and selection

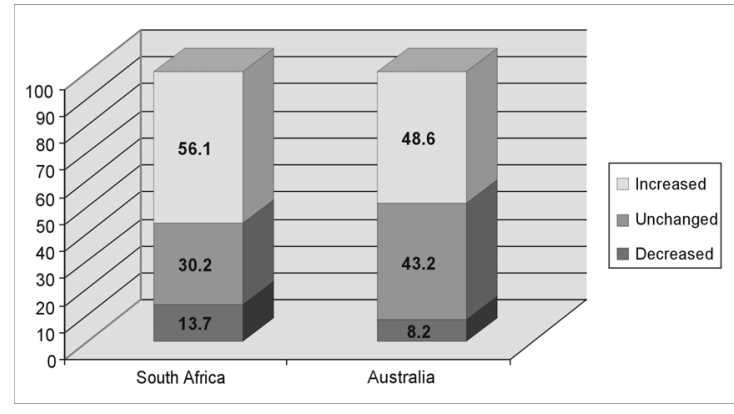

Equal employment opportunity

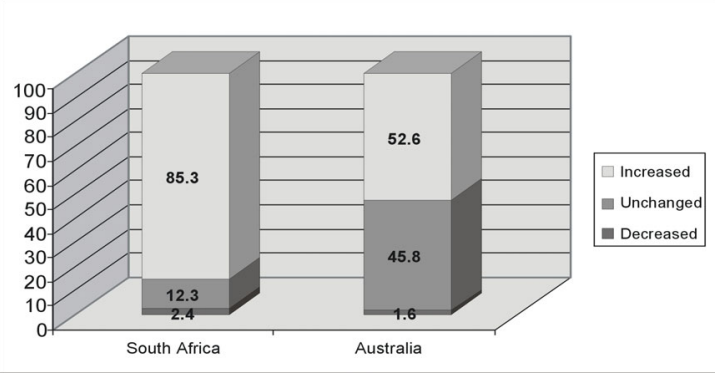

Industrial relations

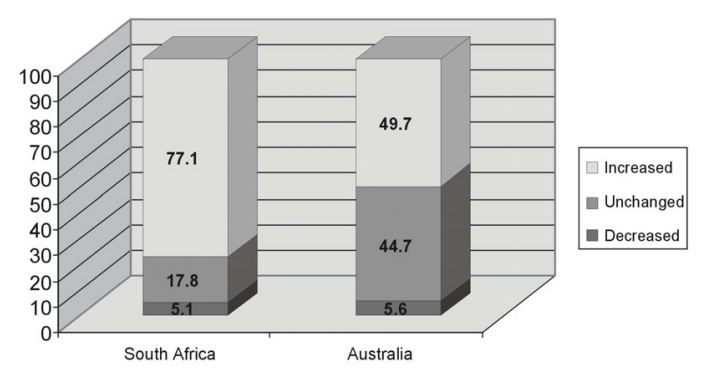

Training and development

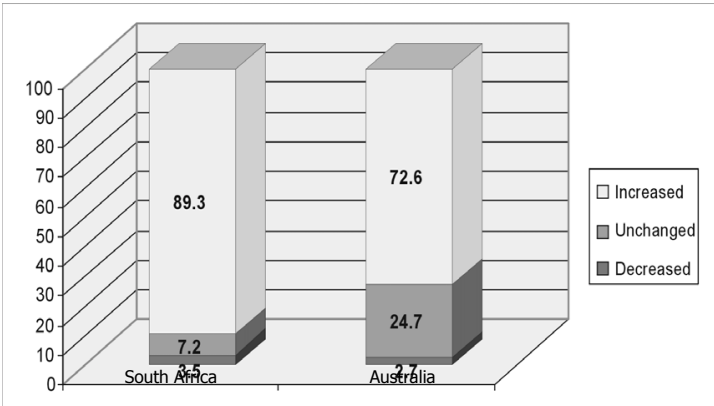

Occupational health and safety

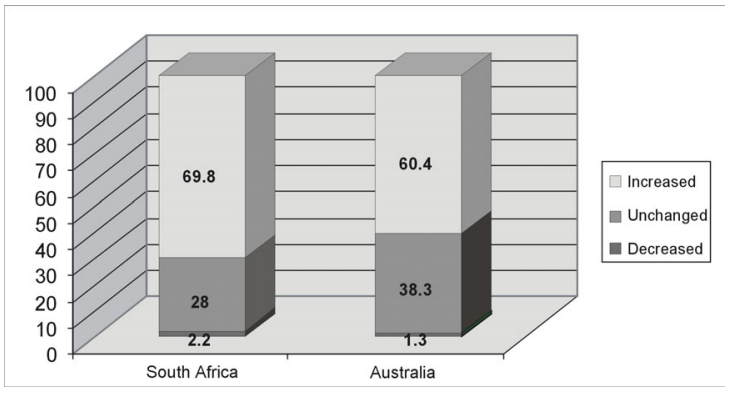

HR information system

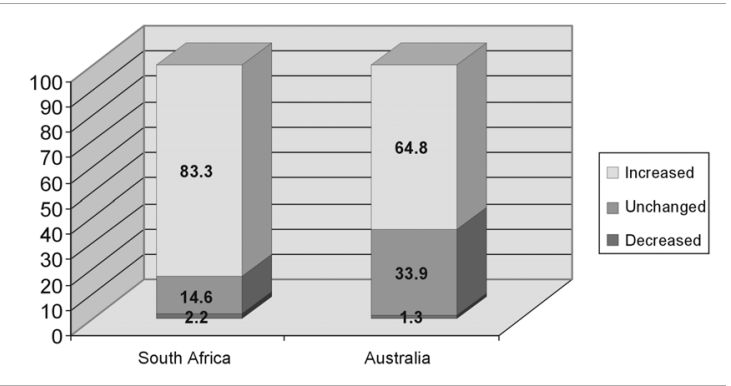


A proportionally smaller number of respondents in Australia indicated an increase in line managers' involvement with human resources management activities. The percentage responses of the Australian respondents were lower for all the human resources activities. The highest percentage responses were also allocated to training and development ( 72,6 per cent), followed by the use of human resources information systems (64,8 per cent), occupational health and safety $(60,4$ per cent), equal employment opportunity (52,6 per cent), and industrial relations $(49,7$ per cent), with recruitment and selection ( 48,6 per cent) as the least important area of change.

The Mann-Whitney U-test was conducted to analyse the difference between South Africa and Australia (independent variables) with reference to each of the six human resources functions (dependent variables). The results are set out in Table 3.

Table 3 Comparison between South African and Australian line managers' involvement in people management: Mann-Whitney U-test

\begin{tabular}{|c|c|c|c|c|c|c|}
\hline $\begin{array}{l}\text { Human } \\
\text { resources } \\
\text { functions }\end{array}$ & Country & $\mathbf{N}$ & $\begin{array}{l}\text { Mean } \\
\text { Rank }\end{array}$ & U-value & $\mathbf{Z}$ & $\begin{array}{l}\text { Sig (2- } \\
\text { tailed) }\end{array}$ \\
\hline \multirow{2}{*}{$\begin{array}{l}\text { Recruitment and } \\
\text { selection }\end{array}$} & South Africa & 371 & 509,85 & \multirow{2}{*}{110984,5} & \multirow{2}{*}{$-1,1653$} & \multirow{2}{*}{0,2439} \\
\hline & Australia & 632 & 490,15 & & & \\
\hline \multirow{2}{*}{$\begin{array}{l}\text { Training and } \\
\text { development }\end{array}$} & South Africa & 375 & 551,99 & \multirow{2}{*}{98630,5} & \multirow{2}{*}{$-6,0162$} & \multirow{2}{*}{$0,0000^{*}$} \\
\hline & Australia & 627 & 471,31 & & & \\
\hline \multirow{2}{*}{$\begin{array}{l}\text { Equal } \\
\text { employment } \\
\text { opportunity }\end{array}$} & South Africa & 374 & 599,22 & \multirow[b]{2}{*}{79767,5} & \multirow[b]{2}{*}{$-10,1189$} & \multirow[b]{2}{*}{$0,0000^{*}$} \\
\hline & Australia & 625 & 440,63 & & & \\
\hline \multirow{2}{*}{$\begin{array}{l}\text { Occupational } \\
\text { health and safety }\end{array}$} & South Africa & 371 & 527,39 & \multirow{2}{*}{105960,5} & \multirow{2}{*}{$-2,8150$} & \multirow{2}{*}{$0,0049^{*}$} \\
\hline & Australia & 627 & 483,00 & & & \\
\hline \multirow{2}{*}{$\begin{array}{l}\text { Industrial } \\
\text { relations }\end{array}$} & South Africa & 371 & 578,24 & \multirow{2}{*}{85240,5} & \multirow{2}{*}{$-7,9971$} & \multirow{2}{*}{$0,0000^{*}$} \\
\hline & Australia & 622 & 448,54 & & & \\
\hline \multirow{2}{*}{$\begin{array}{l}\text { HR information } \\
\text { systems }\end{array}$} & South Africa & 371 & 549,36 & \multirow{2}{*}{93730,5} & \multirow{2}{*}{$-6,0522$} & \multirow{2}{*}{$0,0000^{*}$} \\
\hline & Australia & 616 & 460,66 & & & \\
\hline
\end{tabular}

$* \mathrm{p}<0,01$

The outcome of the Mann-Whitney U-test indicated a statistically significant difference between the respondents in the two countries' perceptions of line managers' involvement with people management in future.

The mean ranks of five dependent variables tested significantly differently at the 99 per cent confidence levels, namely training and development, equal employment opportunity, occupational health and safety, industrial relations and human resources information systems. In all of these cases the mean rankings 
were significantly higher for South Africa. From these results, one can infer that the shift of people management activities to line managers was more prominent in South Africa than in Australia for the period under investigation.

\section{DISCUSSION}

The results indicated that the involvement of line managers in human resources management functions is expected to increase considerably in both countries. The South African respondents differ significantly $(p<0,01)$ from the Australians in their perception of line managers' involvement in five of the human resources management functions two years hence. Recruitment and selection was the only function where there was no difference. The percentage increase expected in people management activities by line managers in South Africa was particularly high in training and development, equal employment, occupational health and safety, industrial relations and information systems.

\section{Reasons for the South African results}

Political, social and industrial democracy in South Africa has historically evolved along racial lines, leading to unique but unfair human resource management practices. This situation came to an end with the April 1994 elections. The new South African Constitution (Act 108/96), government policy and employment laws set the scene for the involvement of CEOs and line managers in promoting equity and non-discriminatory practices in all areas of people management.

The following acts were instrumental in breaking down the employment disparities of the past, to ensure fair, safe and just human resources practices, and to develop a knowledge-based and skilled workforce (Nel, Gerber, Van Dyk, Haasbroek, Schultz, Sono, \& Werner, 2001).

- Occupational Health and Safety Act 85/93;

- Compensation for Occupational Injuries and Diseases Act 130/93;

- Labour Relations Act 66/95;

- Unemployment Insurance Act 30/66;

- Basic Conditions of Employment Act 75/97;

- Employment Equity Act 55/98;

- Skills Development Act 97/98.

These Acts have had and will continue to have a significant impact on employment policies and practices in all sectors of the South African economy. Failure to comply with the last two acts in the workplace could result in the imposition of constraints on the organisation or in direct penalties levelled 
against line managers who do not become directly involved. The result is that CEOs and line managers in South Africa have become much more directly involved with what was traditionally regarded as the domain of specialist human resources practitioners. According to Nel et al. (2001), many organisations in South Africa have transformed their human resources departments from specialised stand-alone functions to a broad strategic corporate practice. Human resources practitioners and line managers are building partnerships to gain competitive advantage and to achieve their business goals. Both South Africa and Australia are adopting a strategic approach to human resources management.

\section{Managerial implications}

In order to meet the challenges of people management under the new dispensation, human resources managers must provide an overall strategy and advice to management. The single biggest challenge for human resources managers is to shift their focus from traditional people management activities to programmes which will address strategic issues as well as managerial and operational areas in future. One of the greatest challenges will be to educate and coach line management about the new paradigm. Future human resources management needs to define new relationships with line management and motivate line managers to develop new skills that will contribute to improving the organisation's people management activities. Human resources professionals must educate and encourage line managers to assume responsibility for managing the human side of business. Finally, they should educate line managers about their critical role in people management in order to achieve a common vision for the future (Gordon, 1987; Ulrich, 1998a; Bernardin, 2003).

Several authors (Gordon, 1987; Howes \& Foley, 1992; Tyson, 1995) are of the opinion that top managers are likely to shoulder primary responsibility for ensuring that human resources management is effective across the organisation. Line managers should provide data to top management and human resources professionals about the effectiveness of programmes and practices in their organisations. They should provide data for strategic decisions about human resources in the organisation and regularly assess the effectiveness of human resources management in their unit by evaluating both processes and outcomes. In view of this, Bernardin (2003: 4) believes that line managers will spend more than 50 per cent of their time involved in human resources activities. The effectiveness with which line managers perform the human resources management functions with the tools, data and processes provided by the human resources specialists is the key to competitive advantage through people management. 


\section{REFERENCES}

1 BERNARDIN, J.H. (2003) Human Resource Management. An experiential approach, McGraw-Hill: Boston.

2 BYARS, L.L. \& RUE, L.W. (2000) Human Resource Management, McGraw-Hill: Boston.

3 CASCIO, W.F. (2003) Managing Human Resources, McGraw-Hill: Boston.

4 GORDON, J.R. (1987) Human Resource Management. A Practical approach, Allyn and Bacon, Inc: Boston.

5 GRATTON, L. (1997) "The art of managing people", Financial Times Mastering Management: 251-62.

6 HARDIJZER, C. (1998) "Value added human resources", People Dynamics, March, 18-23.

7 HOWES, P \& FOLEY, P. (1992) Strategic Human Resources Management, McGraw-Hill: Sydney.

8 HUNTER, L.W. (1997) "Choices and the high performance workplace", Financial Times - Mastering Management: 267-73.

9 KEMSKE, F. (1998) "HR's role will change. The question is how? HR 2008 - A forecast based on our exclusive study", Workforce, January, 77(1): 46-60.

10 LAABS, J. (2000) "Strategic HR won't come easy", Workforce, January, 79(1): 52-9.

11 LEE, H. (1998) "Transformation of employment practices in Korean businesses", International Studies of Management and Organisation, 28(4): 26-40.

12 LITTLER, C.R., BRAMBLE, T.A. \& DUNFORD, R. (1995) "National surveys of organisational restructuring in Australia and New Zealand: An analysis", University of Southern Queensland Working paper: 1-47.

13 MATHIS, R.L. \& JACKSON, J.H. (1997) Human Resource Management, West Publishing Company: New York.

14 MORGAN, G.A. \& GRIEGO, O.V. (1998) Easy Use and Interpretation of SPSS for Windows: Answering Research Questions with Statistics, Lawrence Erlbaum Associates: New Jersey.

15 NEL, P.S., GERBER, P.D., VAN DYK, P.S., HAASBROEK, G.D., SCHULTZ, H.B., SONO, T. \& WERNER, A. (2001) Human Resources Management, Oxford University Press: Cape Town.

16 NOE, A., HOLLENBECK, J.R., GERHART, B. \& WRIGHT, P.M. (2000) Human Resource Management. Gaining a Competitive Advantage, McGraw-Hill: Boston.

17 RUNYON, R.P. (1977) Nonparametric Statistics: A Contemporary Approach, Addison-Wesley Publishing Company, Massachusetts. 
18 TYSON, S. (1995) Human Resource Strategy: Towards a General Theory of Human Resource Management, Pitman Publishing: London.

19 ULRICH, D. (1998a) "A new mandate of human resources", Harvard Business Review, January: 125-34.

20 ULRICH, D. (1998b) "The future calls for change", Workforce, January, 77(1): 87-91.

21 VERMEULEN, L.P., LITTLER, C.R. \& WIESNER, M.S. (1997) "Organisational restructuring in South Africa and Australia: A comparative study", Unpublished report to the Human Sciences Research Council: 1-37. 